\section{GOVERNMENT SOURCES OF SOCIAL AND ECONOMIC RESEARCH DATA}

REPORT from the Interdepartmental Com-
mittee on Social and Economic Research*,
issued in December 1950, covers the work of the
Committee to July 1950 . Referring again to the
increasing extent to which central government
departments have become important sources of the
raw material necessary for research in the social
sciences, the report points out that the developments
which have led to this position will assist the progress
of knowledge only if the departments realize the
importance of research to administration, are aware of
the potential research value of much of the informa-
tion which they collect, and able and willing to make
reasonable provision for the needs of research when
processing the material, and are prepared, subject to
necessary safeguards of confidential material, to make
such material available to research workers outside
as well as inside the government service. Even con-
fidential material should be released as soon as
circumstances permit.

The Committee, noting the view expressed by the Select Committee on Estimates in a report for the 1946-47 session that "one of the weakest points in the Government machine ... is the absence of sufficient provision for the identification of scientific problems in day-to-day administration", observes that, while the administrator who is concerned with solving day-to-day problems very rarely has time in which to enlist the aid of research in matters affecting current policy, there are at least two ways in which he can take thought for the future. $\mathrm{He}$ can try to foresee in advance the problems which need investigation, and he can provide for the scientific observation of what is now happening in order that lessons may be learned for the future. On this ground the Committee takes the view that government departments should be encouraged to do research themselves, especially by the application of existing techniques to the material they possess, and that, where they have insufficient material or staff for their purpose, the departments should approach the universities. It is important, too, that departments should be in touch with current research in their field, and the Interdepartmental Committee on Social and Economic Research suggests that they should consider how this can best be achieved and maintained.

Some departments already have well-organized liaison with outside research bodies, and the Committee is always ready to put departments and outside workers into touch with each other. As its work becomes more widely known, it expects to be used more frequently as a clearing-house between official and non-official interests. Already the Committee has helped to relate a project of the Social Research Division of the London School of Economics, involving a survey of certain aspects of occupational and social mobility, to the needs of the Ministry of Labour and National Service. As a result, the Social Survey of the Ministry of Information drew up a modified scheme, carried out the field-work and prepared two sets of punched cards; one set is in the hands of the Social Research Division of the School and the other has been retained by the Social * Report of the Interdepartmental Committee on Social and Stationery Office, 1950.) $6 d$. net.
Survey to prepare a report on those aspects of the inquiry in which the Ministry of Labour and National Service is particularly interested.

Since its last report, the Committee has surveyed the material available in the Ministry of Education and the Board of Trade. The first of these two surveys has been completed except in relation to the school medical service, and the sub-committee responsible for the survey considered very fully the kind of information required for the subjects of most importance to educational research at the present time. While the Committee supports the Ministry's view that every local education authority should maintain individual records of pupils in the schools in its area, it did not feel justified in recommending that at the present time the Ministry should attempt to collect centrally even a sample of such records. It suggested that more complete data about young workers might be obtained when the county colleges came into full operation, and supported the arrangement made by the Ministry of Labour and National Service and the Central Youth Employment Executive for obtaining an industrial analysis for first employment by age of entry, age of leaving school and broad occupational category. It also suggested that it would be helpful, as a measure of failure after leaving school, if the Ministry of Education consulted with the Home Office regarding the possibility of providing an analysis of the occupations and previous education of juvenile offenders. Certain recommendations made regarding the administrative statistics produced by the Ministry have been accepted.

To avoid delaying recommendations to the Board of Trade until the whole of the exceptionally large field has been covered, it has been arranged that the sub-committee should report at convenient stages. Recommendations already made to the Board based on three interim reports of the sub-committee include those arising from a detailed examination of the tabulation schemes for the Census of Production and the Census of Distribution, which endorsed inter alia the possibility envisaged by the Board of marrying data derived from each source about sales. Following the Committee's recommendations, the Board has agreed that in general there would be no objection to the publication of the results of research done within the Board of 'Trade, and examples of material thus made available are: publication in The Times of summaries of the results of research into changes in productivity, by Dr. L. Rostas; and the findings of an inquiry, by Mrs. K. H. Ross, into pre-war workingclass clothing consumption, which has been published in the Journal of the Royal Statistical Society. Other recommendations have been made in the fields of insurance, companies and bankruptey, the administration of enemy property and statisties. Particular attention is directed to the Patent Office, and, in view of the value of the material there, the Committee expresses the hope that it may be possible for information on the long-term trends in invention to be published in the Board of Trade Journal or else. where. Reviews of Patent Office experience, it suggests, would provide a very useful background and would stimulate interest in the possibility of research in the field which it covers. As examples, the Committee cites research into the relations between inventions and the trade-eycle or, on a sample basis, into the number of inventions which are not exploited and the reasons why they are not developed. 
Some concern has been expressed lest material of value to research is not being preserved for use in the future, and the Committee points out that statutory provision has been made for preserving, so far as possible, all important documents in the possession of government departments. Following acceptance by the Public Records Office of a recommendation made in the Committee's first report, the words "or useful for social and economic research" are being added to the appropriate clause in the departmental schodules. Effect is also being given to its recommendation for consultation between the Committee of Inspecting Officers of the Public Record Office and representatives of departments and academic experts. The Committee is also compiling from time to time lists of unpublished documents which departments are prepared to make available to research libraries and is circulating them to some sixty university and other such libraries; four such lists have already been circulated. Advice is being given by the Committee on the modification of existing, or introduction of new, statistical tables, and it is also considering the question of the presentation of social statistics for conurbations where single administrative units provide an unsatisfactory basis.

\section{THE FILM IN FUNDAMENTAL EDUCATION}

$\mathrm{T}$

HE actual and potential use of the film as a medium in the education of illiterate peoples has recently been described by Peter Brinson (Film Discussion Groups in Fundamental Education, Film Centre, Ltd,, $1950 ; 1 s$.$) .$

Film discussion groups have been formed in India, Indonesia, China, Mexico, South American countries and various non-self-governing territories of the world. In Brazil, five hundred of the 1,500 projectors distributed during 1949 as part of the radio and cinema service of the Ministry of Health were kerosene-operated projectors for use in rural areas without electricity. Here film shows and radio broadcasts through community listening posts are beginning to provide both the opportunity and the means of starting discussion groups as an additional method of instruction at the disposal of the teacher and as an important link between the film-maker and his audience.

An example of the way films are being, and might be, used in fundamental education at the local level is seen in the territory of the Egba Native Administration in the Western Province of Nigeria.

Excluding Lagos, Nigeria is ruled indirectly through native administrations, having their own treasury, courts, prisons and police, markets, sanitary services and the like. District heads and village heads complete the chain of responsibility. Egba includes within its boundaries about twelve thousand people living in eleven villages around the principal city, Abeokuta. The people are mostly peasants, and 80 per cent are illiterate. There are a number of endemic diseases such as tuberculosis and malaria, public hygiene generally being an urgent concern. Nigeria as a whole is large, equal in land area to France and Italy together, with a total population of thirty million. Relative to its size it is sparsely inhabited, distance and communications constituting one of the key factors in development.
The problems which the area raises are fairly typical of fundamental education areas generally. The people of Egba belong to the Yoruba language group, one of the four main groups in Nigeria, which is the basic language for approximately four million people.

In Lagos, the main administrative centre for Nigeria, there is a Government film production unit which was established in 1950, and which is now beginning to make films for use throughout the country. The administration makes use of films from outside, particularly the productions of the Colonial Film Unit in London. There is, too, a mobile projection service, so far on a restricted scale. In 1948, the number of Government 16-mm. mobile cinema vans in use in Nigeria was reported to be four; it seems unlikely that the total number of projectors available for use in mass education exceeds twenty. Each Government van goes on tour for 3-4 months, visiting fifty to sixty towns and villages on each circuit, giving exhibitions to about a hundred thousand people. The average attendance at each show in Nigeria numbers about two thousand persons. In the case of the Egba native administration, a mobile cinema van visits the area once every six to nine months.

There are no Government schools in the area; but four native schools and twelve missionary schools provide primary education. Although adult education centres have recently been set up in different parts of Nigeria as part of special mass education campaigns, they have not so far been established in Egba. There are, however, additional institutions within the area which are of value in mass education generally, and might also be of particular value for using the film in conjunction with discussion groups. There are a hospital at Abeokuta and dispensaries in most of the larger villages. In nearly all the larger villages, too, there is a church. The people of the area meet to sell their produce at about fourteen marketing points, and there is one farmers' cooperative, totalling 700-800 people, and mostly made up of the richer members of the community. These places - the school, the church, the market place, the dispensary-which are popular meeting places, provide the functional centres on which education and an educational film service can be developed according to the people's interests.

The amount of educational work which can be conducted in the area through films and radio is small. With relatively few receiving sets and a mobile film van visiting the area only once every 6-9 months, the opportunity for conducting experiment or even for building up a concentration of interest around a particular problem, such as farm practice, or public hygiene, is limited. The immediate necessity for film-maker and for educationist is clearly to increase the equipment available. The problem is finance; $16-\mathrm{mm}$. projector units are relatively expensive items of equipment, and the Government must take into account competing claims on public funds. It may be possible, however, for the native administration itself, out of its own treasury, to purchase its own projector to supplement the work of Government units. The farm co-operative may be in a position to assist; private resource could supplement official activity. Although there are few instructors and discussion group leaders, there is a nucleus of people in the community, among the village school teachers-both certificated and uncertificated - the leading members of the co-operative, 